\title{
Archaeology of identity: introduction
}

Can there be an "archaeology of identity"? The title of this volume circumscribes a contested field of research. In particular, it is related to the debate about the ethnic interpretation of archaeological evidence. ${ }^{1}$ This has been a topic of controversy in Germany in recent years, following Sebastian Brather's book "Ethnische Interpretationen in der frühgeschichtlichen Archäologie" and some of his other publications. ${ }^{2}$ However, the present volume is not simply intended to continue the debate. Rather, it discusses the material traces of past identities in a broader sense, of which the question of ethnic interpretation is just one, if important, aspect, and reflects on how archaeological evidence can be inserted into a general picture of the 'migration age'. Three related questions have emerged in recent discussions. Firstly, how can we classify archaeological groups or 'cultures', and to what degree do these correspond to ethnic (or religious, social or other) identities of the past? Secondly, can traces of past self-identification be found in material remains? And thirdly, in what ways have modern national or ethnic identifications shaped such interpretations in the history of research? All three questions are essential, but methodologically, they should be kept apart. They specifically concern the interdisciplinary communication between archaeologists and historians. Therefore, most of the authors of this volume are to some degree familiar with both disciplines. Several contributions (Csanád Bálint, Irene Barbiera, Bonnie Effros, Cristina La Rocca/Stefano Gasparri, Piero Majocchi and Premysłav Urbańczyk) deal with the changing interpretation of archaeological evidence in the context of modern identity constructions, and thus add a valuable dimension to contemporary debates. ${ }^{3}$ Others take an exemplary look at methodologically sensitive research questions mainly concerning the $5^{\text {th }}$ and $6^{\text {th }}$ centuries (Hubert Fehr, Jörg Kleemann, Dieter Quast, and Peter Stadler). The picture is completed by two methodological contributions from members of the 'Freiburg school' (Sebastian Brather and Philipp von Rummel). ${ }^{4}$

${ }^{1}$ See, for instance, Siân Jones, The Archaeology of Ethnicity. Constructing Identities in the Past and Present (London/New York 1997); Cultural Identity and Archaeology. The Construction of European Communities, ed. Paul Graves-Brown/Siân Jones/Clive Gamble (London/New York 1996); Lynn Meskell, Archaeologies of identity, in: Archaeological Theory Today, ed. Ian Hodder (Cambridge/Oxford/Malden 2001) 187-213. I am grateful to Nicola Edelmann and Maya Maskarinec for corrections of this article, and to Helmut Reimitz and Pavlina Rychterová for suggestions.

2 Sebastian Brather, Ethnische Identitäten als Konstrukte der frühgeschichtlichen Archäologie, in: Germania 78 (2000) 139-177; id., Ethnische Interpretationen in der frühgeschichtlichen Archäologie. Geschichte, Grundlagen und Alternativen (RGA Erg. Bd. 42, Berlin/New York 2004); for a different opinion, Volker Bierbrauer, Zur ethnischen Interpretation in der frühgeschichtlichen Archäologie, in: Die Suche nach den Ursprüngen. Von der Bedeutung des frühen Mittelalters, ed. Walter Pohl (Forschungen zur Geschichte des Mittelalters 8, Wien 2004) 45-84, and id., Ethnos und Mobilität im 5. Jahrhundert aus archäologischer Sicht: Vom Kaukasus nach Niederösterreich (Abhandlungen der Bayerischen Akademie der Wissenschaften N.F. 131, München 2008). See also Claus von Carnap-Bornheim, Hans-Jürgen Eggers und der Weg aus der Sackgasse der ethnischen Deutung, in: Eine hervorragend nationale Wissenschaft. Deutsche Prähistoriker zwischen 1900 und 1995, ed. Heiko Steuer (RGA Erg. Bd. 29, Berlin/ New York 2001) 173-198; Soziale Gruppen - kulturelle Grenzen. Die Interpretation sozialer Identitäten in der Prähistorischen Archäologie, ed. Stefan Burmeister/Nils Müller-Scheeßel (Tübinger Archäologische Taschenbücher 5, Münster 2006). See also the contribution by Philipp von Rummel, in this volume.

${ }^{3}$ See also the volumes Vergangenheit und Vergegenwärtigung, ed. Helmut Reimitz/Bernhard Zeller (Forschungen zur Geschichte des Mittelalters 14, Wien 2009); Gebrauch und Missbrauch des Mittelalters, 19.-21. Jahrhundert/Uses an Abuses of the Middle Ages: $19^{\text {th }}-21^{\text {st }}$ Century/Usages et Mésusages du Moyen Age du XIX au XXI siècle, ed. János M. Bak/Jörg Jarnut/Pierre Monnet/ Bernd Schneidmüller (MittelalterStudien 17, Paderborn 2009); Nationalism and Archaeology, ed. John A. Atkinson/Iain Banks/ Jerry O’Sullivan (Glasgow 1996); Heinrich Härke, Archaeologists and migrations: A problem of attitude?, in: Current Anthropology 39 (1998) 19-45; Eine hervorragend nationale Wissenschaft. Deutsche Prähistoriker zwischen 1900 und 1995, ed. Heiko Steuer (RGA Erg. Bd. 29, Berlin/New York 2001); Inventing the Pasts in North Central Europe. The National Perception of Early Medieval History and Archaeology, ed. Matthias Hardt/Christian Lübke/Dittmar Schorkowitz (Bern 2003); and themed edition: Early Medieval Material Culture in the Nineteenth- and Twentieth-Century Imagination, ed. Bonnie Effros/Howard Williams, in: Early Medieval Europe 16, 1 (2008) 1-88. For the history of "culture-historical archaeology" and its nationalist uses (including Asian examples), see Bruce G. Trigger, A History of Archaeological Thought (Cambridge 1989) 148-206.

${ }^{4}$ Unfortunately, Volker Bierbrauer and Guy Halsall could not attend the workshop, whereas Florin Curta and Falko Daim chose not to publish their contributions. 


\section{IDENTITY, ETHNICITY}

The word 'identity' has recently become common in archaeological debates, and has appeared in the title of two conferences held in 2005, one in Freiburg entitled "Gräber, Siedlungen und Identitäten. Das 4.-7. Jahrhundert im Westen", ${ }^{5}$ and the other at Mikulov in Moravia, co-hosted by the Prähistorische Kommission of the Austrian Academy, "Barbaren im mittleren Donauraum - Zur Veränderung der Identitätsphänomene”. 6 Identity is a broader term than ethnicity; we could try to describe the identities of, for instance, Roman officers, pagan senators, Egyptian hermits, steppe shamans, women in barbarian warrior families along the Elbe or the urban elites of metropolitan cities in the western Mediterranean. Few of these identifications are as clearly labeled as ethnic identities, which connect a - real or notional - group with a name. Then and now, this makes a fundamental difference, because the group thus named can become a topic for political, affective or scholarly communication, and thus acquire a currency that unnamed social groups, networks or communities do not have. But, again then and now, the seeming validity of the ethnonym may be misleading. What is being perceived as a solid group by outside observers need not correspond to any strong self-identification, and may simply represent an ethnographic or political classification using outdated or misconceived ethnic names to describe a much more complex reality. This creates a methodological problem for early medieval studies because most of our written sources represent outside views, not clear self-identifications. We can infer that people who repeatedly act as a group also identify with it. But we need to be aware that a name does not correspond automatically with a group (as the term 'ethnicity' suggests), but that the identification has to be made plausible in each case (an approach that the term 'identity' allows for).

'Identity' is perhaps a problematic term. ${ }^{7}$ It may be understood in rather different ways, as static or dynamic, as objective or subjective, as social or individual, as factual or as constructed. ${ }^{8}$ As a complex category, it certainly is difficult, if not impossible to define in a satisfactory way (which has often been held against it). There is in fact a danger that it could be used in a reductive and affirmative manner. Claims of past identities may be part of deliberate or implicit politics of identity that seek to establish certain sets of cultural values and social norms across a rather varied population: for instance, the attempts to argue that Europe has a Christian identity, that the Bosnian Muslims are in fact Serbs, or that the Turks are (or are not) Europeans. ${ }^{9}$ The term 'identity' can thus be used as an ideological tool. That is of course also true of many terms that describe human groupings, such as race, ethnicity, nation, people, tribe, class, elite and others, most of which are hard to dispense of when writing history. But thus critical reflection becomes all the more necessary.

The success of 'identity' both in the scholarly and the public spheres is after all due to its explanatory potential. If we say that individual X belongs to group $\mathrm{A}$, this is a straightforward statement that can be tested against the perceptions of $\mathrm{X}$ himself, of the 'ingroup' $\mathrm{A}$, of the others (the 'outgroup'), and against their respective behaviour. ${ }^{10}$ At the same time, we establish a binary logic (does/does not belong) that simplifies the many ambiguities of social groupings, and makes it very hard to decide who belongs where if our evidence is patchy. If, however, we assume that $\mathrm{X}$ has an ' $\mathrm{A}$ '-identity, we say both more and less than that. We claim, on the one hand, that being an A is an important part of X's personality and thus link him/her with a cluster

\footnotetext{
${ }^{5}$ Gräber, Siedlungen und Identitäten. Archäologie des 4.-7. Jahrhunderts im Westen, ed. Sebastian Brather (RGA Erg. Bd. 57, Berlin/New York 2008).

${ }^{6}$ The conference in December 2005 was part of the series "Probleme der Archäologie des mittleren Donauraumes"; the proceedings will be published.

${ }^{7}$ For a fundamental critique of the use of the term in the humanities and social sciences, see Lutz Niethammer, Kollektive Identität. Heimliche Quellen einer unheimlichen Konjunktur (Reinbek 2000); cf. also Francesco Remotti, Contro l’identità (Roma/ Bari 2001), which in spite of its title does employ identity as an analytical category. See also Identitäten, ed. Aleida Assmann/ Heidrun Friese (Frankfurt a. M. 1998); and the useful synthesis by Antonia Davidovic, Identität - ein unscharfer Begriff. Identitätsdiskurse in den gegenwartsbezogenen Humanwissenschaften, in: Soziale Gruppen - kulturelle Grenzen. Die Interpretation sozialer Identitäten in der Prähistorischen Archäologie, ed. Stefan Burmeister/Nils Müller-Scheeßel (Münster etc. 2006) 39-58.

${ }^{8}$ Walter Pohl, Identität und Widerspruch. Gedanken zu einer Sinngeschichte des Frühmittelalters, in: Die Suche nach den Ursprüngen. Von der Bedeutung des frühen Mittelalters, ed. Walter Pohl (Forschungen zur Geschichte des Mittelalters 8, Wien 2004) 23-36; id., Aux origines d'une Europe ethnique: Identités en transformation entre antiquité et moyen âge, in: Annales: Histoire, Sciences sociales 60, 1 (2005) 183-208.

${ }^{9}$ Cf. Mythen der Nationen. Ein europäisches Panorama, ed. Monika Flacke (München/Berlin 1998); Patrick J. Geary, The Myth of Nations: The Medieval Origins of Europe (Princeton/Oxford 2001).

${ }^{10}$ A good introduction into social identity theory in the social sciences is Social Identity Processes, ed. Dora Capozza/Rupert Brown (London/Thousand Oaks 2000).
} 
of identity-relevant historical, social, cultural and political phenomena. On the other hand, the term 'identity' is much more open and flexible than the logic of belonging. It implies that an individual may be related to several groups to different degrees (or 'salience'), and that the identity of these groups in turn may be rather complex and dynamic. ${ }^{11}$ In that sense (and not in any essentialist or static sense), 'identity' seems to be very appropriate for the communication between historians and archaeologists, provided that it is used in a critical and methodologically sound manner. It is possible to detect stronger or weaker signs of (for instance) Gothic or Christian identity in burials, without having to claim that an individual (or a population) actually is a Goth or a Christian.

What 'identity' describes is the interface between the individual and the social group. Sociologists distinguish between individual and collective (or better, social) identities. ${ }^{12}$ But it is important that we realize the dynamic relationship between both. Individuals are hardly ever only idiosyncratic, but are also defined by their social roles and relationships to others. Certainly this was the case in the pre-modern period when personal identity was to a considerable extent created with reference to social groups and cultural models (although not simply imposed by them). ${ }^{13}$ More than historical research based on written sources, archaeology has the opportunity to find the traces of a great number of individuals through their funerary remains, and to hypothesize about their 'personhood' in the context of exchanges and 'dividuality.'. ${ }^{14}$ But only shared characteristics allow for the reconstruction of a more general picture. There are countless ways of showing that one belongs, but they will only be recognizable if they occur frequently.

On the other hand, it would be too simple to assume that identity is a straightforward expression of peoples' sense of belonging to a given ethnic group. Richard Jenkins warns against "our tendency to reify ethnicity": "Although they are talked about endlessly in these terms, neither ethnicity nor culture is 'something' that people 'have', or, indeed, to which they 'belong”". ${ }^{15}$ Rogers Brubaker has called this reifying approach "groupism": "The tendency to take bounded groups as fundamental units of analysis, and basic constituents of the social world." ${ }^{16}$ Identity, and especially ethnic identity, does not necessarily have to refer to a well-delineated social group with a definite number of members. It also "works through categories, schemes, encounters, identifications, languages, stories, institutions, organizations, networks and events." ${ }^{\prime 17}$ It may be that in many cases all of these (and many more) elements coincide and contribute to shaping a basically coherent and stable ethnic identity. Perhaps there is such a thing as the typical Englishman or Spaniard. But in the study of past identities, we can never automatically infer one element from the other. For instance, someone who identified himself as a Hun in an encounter with Byzantine diplomats may have spoken Gothic as his native language, spent much of his life serving as a bodyguard for Aetius, then fought for Attila, used a rather eclectic but typical 'mode danubienne' outfit and have been regarded as a Scythian by the Byzantines. We may decide, not unreasonably, to classify him as a Hun in our scholarly reconstruction of the period, or perhaps, as a Gothic member of the Hunnic warrior elite. But we should not make too far-reaching assumptions about the coherence of either of these identities and their impact. The term 'identity' has acquired the necessary flexibility to describe such dynamic identifications. But for that purpose, we have to acknowledge, quite paradoxically, that identities are never identical. Even our typical Englishman may feel more British than English at times, have an Irish grand-

${ }^{11}$ In the social sciences, the 'self-categorization' and the 'comparative identity' approaches have abandoned binary concepts (ingroup vs. outgroup) to study the "degrees of identification with two" (or more) "categories at different levels of inclusion”, for instance, regional/national identifications: María Ros/Carmen Huici/Angel Gómez, Comparative identity, category salience and intergroup relations, in: Social Identity Processes, ed. Dora Capozza/Rupert Brown (London/Thousand Oaks 2000) 81-95; Social Identity and Intergroup Relations, ed. Henri Tajfel (Cambridge 1982); Rediscovering the Social Group: A Self-Categorization Theory, ed. John C. Turner et al. (Oxford 1987).

12 See, among others, Anthony D. Smith, The Ethnic Origins of Nations (London 1986); Ethnic Identity. Creation, Conflict and Accommodation, ed. Lola Romanucci-Ross/George A. de Vos (Walnut Creek/London 1995); Questions of Cultural Identity, ed. Stuart Hall/Paul du Gay (London/Thousand Oaks 1996).

${ }^{13}$ Walter Pohl, Ego trouble: Introduction, in: Ego Trouble. Authors and their Identities in the Early Middle Ages, ed. Richard Corradini/Matthew Gillis/Rosamond McKitterick/Irene van Renswoude (Forschungen zur Geschichte des Mittelalters 15, Wien 2010) 9-22.

${ }^{14}$ Chris Fowler, The Archaeology of Personhood (London 2004); Jos Bazelmans, Beyond power. Cermenonial exchanges in Beowulf, in: Rituals of Power from Late Antiquity to the Early Middle Ages, ed. Frans Theuws/Janet Nelson (The Transformation of the Roman World 6, Leiden/Boston/Köln 1999) 311-375; Howard Williams, Review article: Rethinking early medieval mortuary archaeology, in: Early Medieval Europe 13, 2 (2005) 195-218, at 209.

15 Richard Jenkins, Rethinking Ethnicity. Arguments and Explorations (Los Angeles $\left.{ }^{2} 2008\right)$.

${ }^{16}$ Rogers Brubaker, Ethnicity without Groups (Cambridge, Mass./London 2004) 2.

17 Brubaker, Ethnicity 3. 
mother, be born in a colony, prefer Balti to Sunday roast or have a French wife. ${ }^{18}$ Among the many identifications that correspond with an ethnic (or national) identity, there are usually some that do not coincide.

In recent scholarly literature, especially in English, the variability and complexity of ethnic identities is often rendered through the shorthand term 'socially/culturally constructed' ${ }^{19}$ Basically, this refers to the classical sociological insight that all social reality is constructed by human practice and perception according to cultural models. ${ }^{20}$ But the formula has acquired a subtext that goes beyond that. Either it presumes that ethnicity was completely malleable and evanescent, and/or it corresponds to a general sentiment that ethnic identity did not matter much in history. ${ }^{21}$ Sometimes this is complemented by a deep-rooted scepticism that early medieval sources cannot tell us much about complex phenomena such as ethnicity anyway. ${ }^{22}$ To claim that ethnicity did not matter much is a comprehensible reaction to the misuse of ethnic identities in the history of the $20^{\text {th }}$ century. ${ }^{23}$ It also reflects the modern experience of nationalist politics: the conscious and sometimes cynical attempt to manipulate ethnic identities as a means of buttressing and expanding the power of a 'national' elite. Along these lines, Patrick Amory has represented Ostrogothic identity in Italy as "ethnographic ideology" manipulated by its rulers to guarantee the privileges of a governing military caste. "Such an evanescent identity cannot be called ethnic, unless we wish to make ethnicity such a flexible term as to be almost meaningless", is what he concluded. ${ }^{24}$ But if being classed as a Goth in Theoderic's Italy conferred privilege, why should we assume that these Gothic soldiers and their families did not 'really' think of themselves as Goths, but only pretended? In the sales document P. Ital. 34 from 551, the clerics of an Arian church in Ravenna (under Byzantine rule since 540) sell off church possessions in an evident hurry; but they subscribe in the Gothic language and call their church ecclesia gotica, basilica Gothorum, and ecclesia legis Gothorum, although at this point it was hardly politically convenient to make such statements of Gothic and Arian identity. ${ }^{25}$ They were about to lose their privilege, and it would have been more expedient to avoid all hints of 'gothicness'. Late antique and early medieval ethnic identities were flexible to differing degrees, but certainly not fluid, purely arbitrary or meaningless. We have a number of cases where people maintained them when it would have been more profitable to join the winners.

The fact that ethnic identities were socially constructed does not mean at all that they did not exist. Otherwise, why are our sources filled with them? Why did contemporary historiography consistently attribute political agency to gentes, peoples? ${ }^{26}$ The Huns plunder, the Franks send an embassy or the Lombards raise a king. Ethnic groups act, they engage in politics and go to war. Traditionally, no scholar even felt the need to explain this, since modern historiography largely agreed that it was nations and peoples that made history. But perhaps, it would be more accurate to say that history was made in their name. Late antique and early medieval peoples were in no way the stable and self-conscious ethnic groups that traditional historiography thought

${ }^{18}$ Cf. Robert Colls, Identity of England (Oxford 2002).

${ }^{19}$ For instance, in Florin Curta, Some remarks on ethnicity in medieval archaeology, in: Early Medieval Europe 15, 2 (2007) 159-185, at 184.

${ }^{20}$ Peter L. Berger/Thomas Luckmann, The Social Construction of Reality: A Treatise in the Sociology of Knowledge (Garden City, New York 1966). See also Pierre Bourdieu, Outline of a Theory of Practice (Cambridge 1977).

${ }^{21}$ A strong statement to that effect: Walter Goffart, Barbarian Tides. The Migration Age and the Later Roman Empire (Philadelphia 2006) 1-12, who, however, polemicizes against a rather outdated form of 'ethnogenesis theory'.

22 An interesting thought-piece along those lines is Timothy Reuter, Whose race, whose ethnicity? Recent medievalists' discussions of identity, in: id., Medieval Polities and Modern Mentalities, ed. Janet L. Nelson (Cambridge 2006) 100-109: "In the first millennium, the definition of others does not appear to have much to do with the definition of self” (101). It is of course crucial to distinguish self-identification and identification by others. But where we have statements of ethnic self-identification they correspond, as a rule, to the perceptions of other sources.

${ }^{23}$ Nationalism as a transitory stage in history: Eric J. Hobsbawm, Nations and Nationalism (London 1996); as constructing largely imagined communities: Benedict Anderson, Imagined Communities. Reflections on the Origin and Spread of Nationalism (London/New York ${ }^{2} 1991$ ); The Invention of Tradition, ed. Eric J. Hobsbawm/Terence Ranger (Cambridge 1983).

${ }^{24}$ Patrick Amory, People and Identity in Ostrogothic Italy, 489-554 (Cambridge 1997) 317. For different views, see Herwig Wolfram, Die Goten. Von den Anfängen bis zur Mitte des 6. Jahrhunderts (Wien/München $\left.{ }^{3} 1990\right)$; Peter J. Heather, The Goths (Oxford/ Cambridge, Mass. 1996); Walter Pohl, Die Völkerwanderung. Eroberung und Integration (Stuttgart/Berlin/Köln ${ }^{22} 2005$ ) 13-30; $126-151$.

25 P. Ital. 34, ed. Jan-Olof Tjäder, Die nichtliterarischen lateinischen Papyri Italiens aus der Zeit 445-700. 2 vols. (Lund/Stockholm 1955/82) 2, 102.

${ }^{26}$ Walter Pohl, Regnum und gens, in: Der frühmittelalterliche Staat - europäische Perspektiven, ed. Walter Pohl/Veronika Wieser (Forschungen zur Geschichte des Mittelalters 19, Wien, in print) 439- 450; id., Die ethnische Wende des Frühmittelalters und ihre Auswirkungen auf Ostmitteleuropa. Oskar-Halecki-Vorlesung - Jahresvorlesung des Geisteswissenschaftlichen Zentrums Geschichte und Kultur Ostmitteleuropas 2006 (Leipzig, forthcoming). 
them to be. Therefore, it is all the more striking that all relevant post-Roman kingdoms were named after peoples. ${ }^{27}$ This was the result of historical change from an empire governed by a ruling elite whose origins mattered relatively little as long as they shared certain cultural codes. ${ }^{28}$ The elites of the Gothic or Frankish kingdoms could also come from quite different backgrounds. But they relied on tribal solidarities, and their identities were much more distinctive than the imperial Roman identity. Our written sources do not allow for much to be said about these identities when the barbarians took power, but eventually, ethnic self-identification and myths of common origin appear more clearly. Ethnic identities were not simply 'there'; they were the result of identifications, of concrete action, social knowledge and of 'strategies of distinction'. ${ }^{29}$

What we can grasp in the written sources are not the 'natural' affiliations of individuals to social groups and their inborn sense of belonging. Rather, the texts represent the political and cognitive uses made of ethnic identifications, negotiations for identity and loyalty, and (on the Roman side) fears of the dynamic of barbarian aggregation. Histories project the ethnic groups of the present into a glorious or barbarian past; law-codes prescribe what members of a people or a kingdom should and should not do; ethnographical passages sketch a broader ethnic landscape; charters confer privileges in the name of a king or his nobles; Christian liturgy and church councils help to give providential meaning to the kingdom; and so on. These texts are often more projective than reflective, they offer identifications and contribute to constructing a meaningful social world. Generally, the early-medieval texts are much more concerned with defining and delineating Christian identities than ethnic ones. But at the same time, they frame a political landscape that is formed by peoples which also have an essential role to play in the history of salvation. What exactly it meant for an individual to be a Goth in Theoderic the Great's, or a Frank in Clovis's, kingdom is difficult to establish. But we know that it made a difference for many contemporary sources. Most of the texts may not have created affiliations; but they made sense of them and gave them meanings. In this respect, many texts written from the late fourth century onwards were part of the effort to give shape and significance to a new order in the Roman provinces in which ethnic identities played a conspicuous role.

What we can observe in the development of textual witnesses from Late Antiquity to the Early Middle Ages is a gradual change of perspective. To classical authors, ethnicity had been a quality of 'the Other', the barbarians. According to Aristotle, the Greeks lived in the polis, whereas the barbarians belonged to ethne tribes or peoples. ${ }^{30}$ In the sixth century, Latin authors writing in the post-Roman regna (and often from important political positions or in close contact with the courts of the new rulers), or from close acquaintance with them, began to modify this perspective: Cassiodorus, Jordanes, Gregory of Tours or Isidore of Seville did not identify directly with the ruling gens, but they legitimized its rule or took it for granted. Fredegar, Bede or the Carolingian Annals completed the shift towards self-identification with the people, which they considered to be chosen by God to rule over former Roman provinces.

\section{TRIBES, PEOPLES}

Similar to ancient ethnography, nineteenth- and early twentieth-century ethnology again used ethnicity as an organizing principle for 'them', the 'primitive' peoples that Europeans met in the course of their colonial expansion, who were classed in tribes, however adequate that happened to be. ${ }^{31}$ In this view, a tribe was distinguished by its specific culture that was the chief object of the discipline of ethnology. ${ }^{32}$ "Thus, while on the one hand the difference between 'them' and 'us' was firmly established, on the other, the basic similarity between different sorts of 'them' was proclaimed.” 33 The concept of the tribe provided a universally-

\footnotetext{
${ }^{27}$ Andrew Gillett, Was ethnicity politicized in the earliest medieval kingdoms?, in: On Barbarian Identity - Critical Approaches to Ethnogenesis Theory, ed. Andrew Gillett (Turnhout 2002) 85-121, is correct that official ethnic self-denomination in the regna was patchy at first. But it did catch on; and in historiography, the identification of regnum and gens is overwhelming.

${ }^{28}$ Cf. Andrea Giardina, L’Italia Romana - storie di una identità incompiuta (Roma/Bari 1997).

${ }^{29}$ Walter Pohl, Telling the difference - Signs of ethnic identity, in: Strategies of Distinction. The Construction of Ethnic Communities, 300-800, ed. Walter Pohl/Helmut Reimitz (The Transformation of the Roman World 2, Leiden/New York/Köln 1998) 17-69, reprinted in: From Roman Provinces to Medieval Kingdoms, ed. Thomas F.X. Noble (Rewriting History, London/New York 2006) 120-167; id., Die ethnische Wende.

30 Aristoteles, Politika 1261a; 1276a.

31 Jean-Loup Amselle, Logiche meticce. Antropologia dell'identità in Africa e altrove (Torino 1999).

${ }^{32}$ For the $18^{\text {th }}$-century origin of a definition of non-European peoples by their respective 'culture', see Niklas Luhmann, Gesellschaftsstruktur und Semantik (Frankfurt a. Main 1999) 145ff.

33 Jenkins, Rethinking Ethnicity 18.
} 
applicable model for 'archaic' social organisation. It did not only allow for distinguishing between different tribes (and often enough, just as the Romans did with their neighbours, to play them off against each other). It also allowed for hypothesizing a distinctive 'primitive' period in the cultural evolution of mankind, a 'tribal phase'. ${ }^{34}$ Tribes, according to a recent definition, are societies "which create all or most of their social roles by ascribing social importance to biological characteristics, in other words, societies ordered with reference to kinship, sex and age.”35 Of course, the common descent of a tribe need not be biological fact, but rather a genealogical construction. Other anthropologists try to define the tribe by objective characteristics, underlining common economic factors or political organisation. It has also been described as a "state of mind". ${ }^{36}$ Whatever was common to a tribe, it was as much defined by who did not belong to it. ${ }^{37}$ Tribal organisation provided a simple and efficient logic to channel and escalate conflict by involving additional groups according to an essentially binary structure of inclusion or exclusion, regardless of their interest in what the original cause of the dispute may have been. This logic of dispute is usually defined as bloodfeud, but may need a more complex explanation. ${ }^{38}$ In short, what emerges from recent research is the great variety of forms of tribal organisation. Tribes may be pastoral or sedentary, they may be settled in a common territory or scattered among others, they may share a common political organisation or live in autonomous clans or villages, and they may be subject or related to a state, resist its influence or have no contact at all to more complex forms of social organisation.

An interesting example of the dialectic of tribe and empire is the early Islamic World, especially as it can be compared to the parallel, but very different development of the relationship between ethnic groups and states in the early medieval West. ${ }^{39}$ In a very general sense, it could be said that most of the Islamic conquerors of the seventh century were Arabs. But beneath this sweeping ethnic identification, there was a tribal coalition forged by a dynamic new religion and reinforced by other converts. Unlike the barbarians who built their kingdoms on the territory of the Western Empire, in the east no single ethnic groups established their rule over one or several former Roman provinces. Still, many of the Islamic conquerors preserved (or recreated) their ethnic ties. In the ninth century when sources become more detailed, there were some cities and regions in which tribal solidarities constituted a considerable political potential, like Mossul or the country around Damascus; and others where they do not seem to have been important at all (such as the city of Damascus itself). In many of these areas dominated by tribal affiliations, tribes were settled in different villages in a rather dispersed way. ${ }^{40}$ The rich ethnic terminology in Arabic seems to reflect a whole hierarchy of tribal affiliations, from the people of the Arabs, within which there was an opposition between the inclusive tribal groupings of the Yaman (originally 'Yemenite' south Arabians) and the (North Arabic) Qais to single tribes, subtribes and clans. This hierarchy was, however, far from systematic, and changes of allegiance were regularly reflected in modifications of genealogy. The Caliphs had to coexist with tribal structures up to a point, but also had a vested interest in not letting them interfere too much in the rule of the Islamic empire. ${ }^{41}$

This brief sketch may suffice here to demonstrate that the role of ethnic identities evolved very differently in the post-Roman West. Even the scholarly terminology has developed differently. Scholars of the Islamic world regularly use 'tribe', and regard 'people' (in their context, the Arabs) as a very vague concept. For the West, Reinhard Wenskus, in the 1960s, still employed the term “Stammesbildung”; but soon after that, 'Stamm' or 'tribe' ceased to be used by most authors, at least for the migration period. ${ }^{42}$ Traditionally, the 'people' of the

${ }^{34}$ See, for instance, Julian H. Steward, Theory of Culture Change (Urbana-Ill. 1955); Isaac Schapera, Government and Politics in Tribal Societies (London 1956).

${ }^{35}$ Patricia Crone, The tribe and the state, in: John A. Hall, States in History (Oxford 1986); reprinted with revisions in ead., From Arabian Tribes to Islamic Empire. Army, State and Society in the Near East c. 600-850 (Aldershot 2008) n. 1. Adding "sex and age" to the definition is interesting in view of the strong cultural accentuation of gender and age in many prehistoric burial complexes.

${ }^{36}$ Richard Tapper, Frontier Nomads of Iran: A Political and Social History of the Shahsevan (Cambridge 1997); for various definitions of tribe, see also Eva Orthmann, Stamm und Macht. Die arabischen Stämme im 2. und 3. Jahrhundert der Hiğra (Wiesbaden 2002).

37 A classic anthropological study of the importance of delimitations of tribes and peoples, and one of the most influential contributions to research on ethnicity altogether, is Frederick Barth, Introduction, in: Ethnic Groups and Boundaries. The Social Organisation of Cultural Difference, ed. id. (Oslo 1969) 9-38.

${ }^{38}$ See, for instance, Violence and Society in the Early Medieval West, ed. Guy Halsall (Woodbridge 1998).

${ }^{39}$ See Crone, The tribe and the state; Orthmann, Stamm und Macht.

${ }^{40}$ For instance in the Gūta around Damascus: Orthmann, Stamm und Macht 81-105.

${ }^{41}$ Crone, The tribe and the state.

${ }^{42}$ Reinhard Wenskus, Stammesbildung und Verfassung. Das Werden der frühmittelalterlichen gentes (Köln/Wien $\left.{ }^{2} 1977\right)$. 
Germans had been seen as constituted by its 'tribes', Saxons, Franks, Bavarians and others; many scholars also regarded Goths, Vandals or Lombards as 'deutsche Stämme', with obvious ideological implications. ${ }^{43}$ A similar view of the genesis of the Polish people from 'its' tribes has recently been refuted by Przemysłav Urbańczyk. ${ }^{44}$ Ideological overtones (and the notion of primitivity) were one reason why the concept of 'tribe' virtually disappeared from early medieval studies. Also, the ethnic groups that formed on Roman territory seem to have reached a size and a degree of complexity that does not correspond with the notion of 'tribe'. But it is worth noting that unlike the Arab language with its rich and differentiated vocabulary for ethnic groups, the most diffused Latin term, gens, does not allow for groups to be distinguished by their size - it can refer to the Agilolfing dynasty and to the Franks alike. A tribal model may in any case be quite accurate to describe the situation in the Germania in the day of Augustus, or at least the Roman perception of it. From the third century onward, the situation became more complicated as larger and often more improvised and unstable groupings began to form.

Arguably, the notion of 'tribe' has little to contribute to understanding, for instance, the formation of Franks and Alemanni, although they have often been pictured as tribal confederations. ${ }^{45}$ Quite generally, the use of ethnic distinctions by early migration-age Romans rarely reflects a discernible self-definition by barbarian descendance groups. There are some cases of ethnic prejudice, for instance when the Goths explained the name of the Gepids as gepanta, 'lazy'. ${ }^{46}$ If tribe is a 'state of mind', we may be surprised by the relative lack of tribal logic in the often dramatic wars and battles of the migration age. Most of the wandering armies had a rather loose structure and fluctuating membership. As many conflicts arose between members of the same ethnic group (many of whom served in Roman armies) as between different tribes. For instance, Gregory of Tours pictures King Clovis as a cynic who uses the language of kinship just to kill off all the potential rivals in his family: "And having killed many other kings and his nearest relatives, of whom he was jealous lest they take the kingdom from him, he extended his rule over all the Gauls. However he gathered his people together at one time, it is said, and spoke of the kinsmen whom he had himself destroyed. 'Woe to me, who have remained as a stranger among foreigners, and have none of my kinsmen to give me aid if adversity comes.' But he said this not because of grief at their death but by way of a ruse, if perchance he should be able to find some one still to kill." ${ }^{\prime 7}$ Thus, a clear pattern of 'tribal' allegiances and enmities could hardly form. Stable tribal systems often prevent the rise of supra-regional powers because the most powerful tribes soon have to face opposition from a broad alliance of those threatened by their expansion. If such a system existed among the northern barbarians in the earlier imperial age, it had obviously collapsed in the early migration period.

That does not mean that ethnic allegiances did not matter at all; but they mattered on a different level. The most successful barbarian groups on Roman territory seem to have used ethnic identifications in the attempt to reinforce the cohesion of their armies. The peoples that formed in the nascent kingdoms seem to have relied increasingly on ethnic solidarities. But it is necessary to historicize the forms of ethnicity that mattered in the migration period. Ethnic identities did not necessarily mean the same in all cases, and the variety of ethnic groups that are attested in the sources between the fourth and the sixth centuries is considerable. Ethnic names may designate one (or several) of the following types of groups: ${ }^{48}$

1. Local groups, villages or extended clans; normally the written sources hardly talk about these. Many of the names in Ptolemaeus or the Bavarian Geographer may be understood in this way.

${ }^{43}$ Cf. Matthias Becher, Rex, Dux und Gens: Untersuchungen zur Entstehung des sächsischen Herzogtums im 9. und 10. Jahrhundert (Husum 1996); Bernd Schneidmüller, Völker - Stämme - Herzogtümer. Von der Vielfalt der Ethnogenesen im ostfränkischen Reich, in: MIÖG 108 (2000) 31-47; Joachim Ehlers, Methodische Überlegungen zur Entstehung des deutschen Reiches im Mittelalter und zur nachwanderzeitlichen Nationenbildung, in: Beiträge zur mittelalterlichen Reichs- und Nationsbildung in Deutschland und Frankreich, ed. Carlrichard Brühl/Bernd Schneidmüller (München 1997) 1-14.

${ }^{44}$ See the contribution by Przemysłav Urbańczyk, in this volume.

45 See, for instance, Alexander Demandt, Die westgermanischen Stammesbünde, in: Klio 75 (1993) 387-406. For a more sceptical view, Walter Pohl, Die Germanen (Oldenbourgs Enzyklopädie der deutschen Geschichte 57, München $\left.{ }^{2} 2002\right) 109 f$.

46 Jordanes, Getica XVII, 95 (ed. Theodor Mommsen, MGH AA 5, 1, Berlin 1882) 82.

47 Gregory of Tours, Histories II, 42 (transl. Earnest Brehaut, New York 1916) http://www.fordham.edu/halsall/basis/gregory-hist. html (13.2.2009).

${ }^{48}$ For a fuller treatment, see Walter Pohl, Die Namen der Barbaren: Fremdbezeichnung und Identität in Spätantike und Frühmittelalter, in: Zentrum und Peripherie. Gesellschaftliche Phänomene in der Frühgeschichte, ed. Herwig Friesinger/Alois Stuppner (Mitteilungen der Prähistorischen Kommission 57, Wien 2004) 95-104; see also id., Spuren, Texte, Identitäten. Methodische Überlegungen zur interdisziplinären Erforschung frühmittelalterlicher Identitätsbildung, in: Gräber, Siedlungen und Identitäten. Archäologie des 4.-7. Jahrhunderts im Westen, ed. Sebastian Brather (RGA Erg. Bd. 57, Berlin/New York 2008) 13-26. 
2. Regional sub-tribes or settlement units, such as the Brisigavi, Lentienses etc. as part of the Alamanni. The names may (as in this example) be derived from toponyms or represent a tribal designation. Evidence on such regional units is also rather rare, both before and after settlement on Roman soil.

3. A special case are bipartite tribal structures within a people or tribe. They usually correspond to double genealogies. For instance, Var und Chunni were the two ancestral units within the sixth-century Avars (or Varchonitai; the name was composed from both elements). ${ }^{49}$ They are not known to have had any political influence, but sources are meagre. It may be that the Gothic Tervingi and Greutungi, the Vandal Hasdingi and Silingi or the Frankish Salii and Ripuarii represented similar sub-units at some stage, although in all cases this assumption has been criticized as a modern projection. ${ }^{50} \mathrm{~A}$ similar double structure underlies the Arab geneaologies that go back to Adnān (the Qais) and Qahtān (the Yaman); unlike other subgroups, they constituted a kind of tribal superstructure that incorporated other tribes within the wide and ambiguous frame of Arab identity. ${ }^{51}$

4. Ethnic groups under foreign rule. This is a wide field; a well-known example are the Rugi under Ostrogothic rule who were said to have deliberately maintained their cohesion by strict endogamy, and were able to raise a Rugian to Gothic kingship half a century after their incorporation in the Gothic kingdom..$^{52}$ The Bulgars under Lombard rule are another case, having been settled under their duke Alzeco in the duchy of Benevento in the second half of the $7^{\text {th }}$ century and still distinguishable in the $10^{\text {th }}$ century; or the Saxons of Bayeux in the Merovingian kingdom. Whereas these groups seem to have been able to maintain some regional cohesion, other groups, such as the Gepids under Avar and Lombard rule, preserved their identity at the village level. Archaeologists often explain divergent evidence within a larger group with the existence of such ethnic minorities (see the contribution by Peter Stadler, in this volume); but usually, those are equations with too many variables.

5. Autonomous tribes or peoples on a regional level with relatively coherent settlement areas. In the early imperial Germania, that seems to have been the predominant mode of social organisation of, for instance, Cherusci, Chauci, Marsi, Chatti and others. Hardly any of the politically active peoples of the migration period fit this model; perhaps the peoples settled north of the Danube after Attila's death offer an example, but even there, no balanced tribal system emerged.

6. Peoples who lived scattered over several settlement areas, or names that occur in more than one region, for instance the Goths and Heruls in the $4^{\text {th }}$ to $6^{\text {th }}$ centuries, the Alans and the Suebi of the $5^{\text {th }}$ and $6^{\text {th }}$ centuries, and later Bulgars or Croats. This may be a result of separations and migrations (and is usually described that way in the texts); but more likely, it is often the case of a prestigious name adopted by several groups (as Theophylact attests for the Avars ${ }^{53}$ ). A corresponding sense of identity that included some or all of these groups is rarely attested, ${ }^{54}$ but there are some examples (for instance, the Heruls and the Vandals sending messengers into their putative old homelands in Procopius). In some cases, the common name may simply represent an outside perception or a mistake in the sources.

7. Ethnic confederations, tribal unions, agglomerates and groups of tribes with supra-regional significance but weak or nonexistent organisation and often doubtful delimitation, such as the Suebi of the early Empire, the Huns after the death of Attila, or the Yamans and Qais of the Ummayad period. The distinction to ethnographic umbrella terms is fluid, and it is often doubtful whether these names corresponded to strong self-identifications.

49 Theophylactus Simocatta, Histories VII, 7 (ed. Karl de Boor, Leipzig 1887) 257; Walter Pohl, Die Awaren. Ein Steppenvolk in Mitteleuropa, 567-822 n. Chr. (München 1988, $\left.{ }^{2} 2002\right)$ 31ff.

${ }^{50}$ Wolfram, Die Goten 34f.; Helmut Castritius, Hasdingen, in: RGA 2 Aufl. 14 (1999) 26-28; in general id., Die Vandalen (Stuttgart 2007); Matthias Springer, Gab es ein Volk der Salier?, in: Nomen et gens. Zur historischen Aussagekraft frühmittelalterlicher Personennamen, ed. Dieter Geuenich/Wolfgang Haubrichs/Jörg Jarnut (RGA Erg. Bd. 16, Berlin/New York 1997) 58-83; Pohl, Die Völkerwanderung 70f.; 167.

51 Orthmann, Stamm und Macht 210f.; see above.

52 Procopius, History of the Wars VII, 2 (ed./trans. Henry Bronson Dewing, Procopius 4, Loeb Classical Library 173, CambridgeMass./London 1924, reprint 2000) 166-173; Peter Heather, Disappearing and reappearing tribes, in: Strategies of Distinction. The Construction of Ethnic Communities, 300-800, ed. Walter Pohl/Helmut Reimitz (The Transformation of the Roman World 2, Leiden/Boston/Köln 1998) 95-111.

${ }_{53}$ Pohl, Awaren 30f.

54 See the ironical remarks by Reuter, Whose race 102: “We don't know when or how Avar identity ceased to be meaningful to Avars, though it clearly must have done at some point, since there aren't any now. It's far from clear that Avars thought they were Avars when they still were Avars, if you see what I mean.” 
8. Peoples who established supra-regional kingdoms and came to rule over several other peoples and tribes, such as Ostrogoths and Visigoths, Vandals, Franks or Avars. This is a broad category. Typically, the ethnonym becomes ambiguous in the process, denoting both a (usually military) core group and a broader population. In some cases, for instance with the Franks, these realms expand so successfully that the corresponding identities become imperialized and tend to lose their coherence. In other cases, the ruling peoples incorporate the majority of the population and, in the course of time, become more or less territorial, for instance, in England, Lombardy, France or Hungary. But what has long been regarded as the norm in national histories - the ethnically homogeneous, supra-regional nation state - did not even exist as a concept in the Early Middle Ages.

9. Broad denominations by outsiders and ethnographic umbrella terms that as a rule do not correspond to strong self-identifications, but represent the perceptions and classifications of the population of vast areas by (often literate) outside observers, for instance Celts, Germani or Scythians. The early Slavs most likely belong to this category, although it is more likely than in the other cases that the name also expressed some sort of self-definition. ${ }^{55}$ The name of the Huns was also used throughout the Eurasian steppes and the neighbouring civilisations as a generic term, but seems to appear as a self-definition as well (although we cannot be quite sure of that in the case of Attila's Huns).

10. Invented, disappeared or conquered peoples whose names were (re-)used for political or other purposes. A typical example are the Burgundians after the fall of their kingdom, whose prestigious name came to denote one of the Frankish kingdoms, and was reused by a series of rulers thereafter, up to the GrandDucs de l'Occident in the $15^{\text {th }}$ century. The Vinedi/Wends show a specific dialectic: in the early empire, this was the name of a people that lived east of the 'Germans'; in the early middle ages, it was used by speakers of Germanic languages for the Slavs, a usage also taken up in Latin and Greek; from the $9^{\text {th }}$ century, the name was frequently identified with that of the Vandals; and both names were variously appropriated by Slavs as a self-designation from the later Middle Ages onwards. ${ }^{56}$

Most of these names can refer to self-designations as well as to perceptions by outsiders, apart from the last two categories; but even there some of the names could later be used for self-identification. Furthermore, the same name could be used to identify groups in different categories, simultaneously or in turn; 'Goths', for instance, could be regional settlement units or dispersed peoples; some lived under foreign rule while others established supra-regional kingdoms, and consequently their name could also be used, by Procopius, as an umbrella term for the 'Gothic peoples', including Gepids, Vandals and even Sarmatians. ${ }^{57}$ Although our evidence for ethnic self-definition is patchy, we may assume that an individual could identify with more than one of these categories, local, regional, supra-regional, perhaps even with a broad ethnographic category.

\section{AN ARCHAEOLOGY OF IDENTITY?}

It may have become clear from this rough outline that recent developments in the conceptualisation of ethnic identities have not made the task of an 'archaeology of identity' easier. Identity constitutes a relationship, or rather: a bundle of relationships between the individual and the social world. Consequently, the notion of the social group has become more elusive. Seen from this angle, looking for past identities in archaeology is a more complex goal than trying to identify archaeological cultures with ethnic groups. ${ }^{58}$ It has even been

\footnotetext{
55 Fritz Vigener, Bezeichnungen für Volk und Land der Deutschen vom 10. bis zum 13. Jahrhundert (1901, reprint Darmstadt 1976); Reinhard Wenskus, Über die Möglichkeit eines allgemeinen interdisziplinären Germanenbegriffs, in: Germanenprobleme aus heutiger Sicht, ed. Heinrich Beck (RGA Erg. Bd. 1, Berlin/New York 1986) 1-21; Hans-Hubert Anton, Antike Großländer, politisch-kirchliche Traditionen und mittelalterliche Reichsbildung, in: Zeitschrift der Savigny-Stiftung für Rechtsgeschichte, Kanonistische Abteilung 86 (2000) 33-85; Florin Curta, The Making of the Slavs. History and Archaeology of the Lower Danube Region c. 500-700 (Cambridge 2001).

${ }^{56}$ Roland Steinacher, Wenden, Slawen, Vandalen. Eine frühmittelalterliche pseudologische Gleichsetzung und ihre Nachwirkungen, in: Die Suche nach den Ursprüngen. Von der Bedeutung des frühen Mittelalters, ed. Walter Pohl (Forschungen zur Geschichte des Mittelalters 8, Wien 2004) 329-353.

57 The Gothika ethnē comprising (Ostro-)Goths, Vandals, Visigoths and Gepids, but formerly also Sarmatians: Procopius, History of the Wars III, 2, 2 (ed./trans. Henry Bronson Dewing, Procopius 2, Loeb Classical Library 81, Cambridge-Mass./London 1916, reprint 2000) $9 f$.

${ }^{58}$ Cf. Davidovic, Identität 52-56.
} 
doubted whether it is a feasible aim at all. ${ }^{59}$ But maybe the gradual paradigm change in research on identities in the humanities and social sciences also opens up new perspectives for archaeology. A greater variety of forms of social and ethnic groups makes it easier to accommodate very varied evidence. If, for instance, 'archaeological cultures' in the Germania magna of the early imperial age do not correspond to any of the single gentes attested in the written sources, nor give shape to an overall Germanic identity, this constitutes valuable information in itself. On the whole, we need to know more about group structure, range of communication, internal and external relationships and exchange networks. ${ }^{60}$ In this way, archaeological data may help to establish which of the often lofty ethnic identities depicted in historiography have left any detectable traces in the ground. The complexity and interrelationship of various levels of ethnic identification may help to explain why more often than not, ethnically distinctive features in archaeological material, if at all, constitute the exception and not the norm. Many of these forms of ethnicity coexisted in the late ancient and early medieval West. Few of them can be expected to correspond to an 'archaeological culture' at all. At the same time, they existed in a cultural continuum with much more productive and visible modes of identification, for instance Roman imperial civilisation and Christian culture. Under these circumstances, an orderly mapping of social groups on the basis of common cultural traits and written identifications, as hoped for by generations of archaeologists and historians, can hardly be a realistic research goal. On the other hand, there were identities that mattered more than others, and that were in the focus of strategies of distinction, sometimes even emphatically so. Signs and codes of identity, performative and symbolical modes of identification are in most cases inaccessible through material remains, but there may be valuable exceptions.

Archaeologists face a difficult, but fascinating balance between individual and social identities. There may well be truly individual characteristics that a person does not share with anybody else - some unique find in a grave that is unlikely ever to be found in another grave. But in most cases, both archaeologists and historians deal, and have to deal, with what is typical, and with what groups of people share, whether that is a type of fibula or pottery, a certain inhumation rite, a social marker, an ethnic designation or a frequently-used personal name. In our sources, we mostly have access to those traits of an individual identity that make this individual part of a group or that were meaningful for a group. We deal with ways in which people adapted to circumstances and conformed to social groups. And much of what we observe in the sources is part of that process. Yet, neither grave inventories nor medieval manuscripts are natural reflections of self-evident membership in a basically unchanging group. In that case, they might not even be there.

In what is to follow, I will take grave finds as an example because they usually feature prominently in debates on ethnic interpretation. Of course, they are not easy to interpret along these lines. ${ }^{61} \mathrm{~A}$ telling example is the funeral of Pope John Paul the Second in $2005 .{ }^{62}$ His sarcophagus was adorned with the letter M - would an archaeologist of the future guess what that means? It refers to the Virgin Mary. And in his grave there were no insignia of his papacy (apart from his bishop's mitre), but a bag with 27 coins. These were not meant for the fare he had to pay to Charon or to denote his wealth in the afterlife, but were Vatican coins, one for each year of his pontificate (perhaps a way to demonstrate Vatican identity?). The conclusion is clear: What is self-evident need not be highlighted; there are carefully modulated individual accents in the funeral process, even in one as steeped in tradition and liturgy as the burial of a pope. And they may be negotiated - the Polish bishops wanted

${ }^{59}$ Brather, Ethnische Interpretationen, esp. 625-631. His critique of using ethnic categories at all has, however, been exaggerated in the polemic.

${ }^{60}$ Cf. Heiko Steuer, Archäologie und germanische Sozialgeschichte. Forschungstendenzen in den 1990er Jahren, in: Runische Schriftkultur in kontinental-skandinavischer und angelsächsischer Wechselbeziehung, ed. Klaus Düwel (RGA Erg. Bd. 10, Berlin/New York 1994) 10-55.

${ }^{61}$ See, for instance, Falko Daim, Archaeology, ethnicity and the structures of identification: The example of the Avars, Carantanians and Moravians in the eighth century, in: Strategies of Distinction. The Construction of Ethnic Communities, 300-800, ed. Walter Pohl/Helmut Reimitz (The Transformation of the Roman World 2, Leiden/New York/Köln 1998) 71-94; Guy Halsall, Burial writes: graves, 'texts' and time in early Merovingian Northern Gaul, in: Erinnerungskultur im Bestattungsritual. Archäologisch-historisches Forum, ed. Jörg Jarnut/Matthias Wemhoff (München 2003) 61-74; and the useful synthesis by Nils Müller-Scheeßel/Stefan Burmeister, Einführung: Die Identifizierung sozialer Gruppen. Die Erkenntnismöglichkeiten der Prähistorischen Archäologie auf dem Prüfstand, in: Soziale Gruppen - kulturelle Grenzen. Die Interpretation sozialer Identitäten in der Prähistorischen Archäologie, ed. Stefan Burmeister/Nils Müller-Scheeßel (Münster etc. 2006) 9-38.

${ }^{62}$ More extensively treated in Walter Pohl, Spuren, Texte, Identitäten. Methodische Überlegungen zur interdisziplinären Erforschung frühmittelalterlicher Identitätsbildung, in: Gräber, Siedlungen und Identitäten. Archäologie des 4.-7. Jahrhunderts im Westen, ed. Sebastian Brather (RGA Erg. Bd. 57, Berlin/New York 2008) 13-26 (with references to media reports); cf. Agostino Paravicini Bagliani, Der Leib des Papstes. Eine Theologie der Hinfälligkeit (München 1997); id., Mort du Pape, in: Dictionnaire Historique de la Papauté, ed. Philippe Levillain (Paris 1994) 1143-1146. 
to include a small bag of Polish earth in John Paul's grave, but did not succeed. These observations may hold true for many historical burials. At the funeral of Attila the Hun, for instance, one of the few of the period described in a roughly contemporary text, there was no need to demonstrate that he was a Hun. The first thing Jordanes mentions that was put in his grave were arma hostium caedibus adquisita, arms acquired in the slaughter of enemies. ${ }^{63}$ Attila's identity, and the range of his power and success, was highlighted by foreign objects.

The funerals of kings and religious leaders are exceptional in many ways, but they may give us an idea of what could matter. Attila surely was not the only Hun in whose grave the weapons of defeated enemies were put. Quite generally, the core group of Attila's Huns do not seem to have striven to display their Hunnic identity in burial and distinguish themselves from other groups of Attila's subjects. ${ }^{64}$ And whoever dropped tons of Roman swords and armour into southern Scandinavian bogs: they were not Romans. ${ }^{65}$ In both cases, doing such was a strong statement of identity. You do not throw away precious arms (or at least, recyclable metal) without meaning. Indeed, the sense of purpose must be stronger than the value of the objects. The purpose can only lie in symbolic communication with one's own social group, occasionally with other groups, and with the transcendental community of gods and ancestors. Thus, burials can be described as a form of communication between the heirs and the participants in the ceremony about what we could call the identity of the deceased, though in a very general sense: what was remarkable and memorable about him or her. ${ }^{66}$ It may well be that symbolic statements about ethnic identity were most needed in cases when ethnicity was unexpected or otherwise remarkable, and not self-evident. In elite graves (such as Mušov, Childeric's grave at Tournai or Sutton Hoo) ${ }^{67}$, the material could obviously be rather heterogeneous. To display status or individuality by rare and foreign objects is likely to have been a rather diffused practice. ${ }^{68}$ Perhaps that helps to explain why so many distribution maps of early medieval object types cover quite large areas. It is worth noting that the repertoire of the symbolical language employed in migration-age burials is often spread out beyond the regional populations that we tend to identify with ethnic groups.

Of course, the central criterium of ethnic identity that has emerged since Reinhard Wenskus, a subjective sense of belonging, cannot be traced directly in the burial evidence. ${ }^{69}$ However, that does not mean that archaeological evidence gives no clues at all about ethnic identities. Habitus, in the sense of Bourdieu (that is, including not only outward signs but also inner dispositions), may not represent a direct reflection of social identity, but a closely-related concept. ${ }^{70}$ Neither habitus nor identity were completely malleable. What has been said above about the dynamics of identity formation does not imply that ethnic identification is open to choice. There is of course a range of negotiability. I once argued in front of a North Italian audience that it would be impossible to put on a green hat and claim to be a Martian; in the discussion, I was told that it was after all possible to put on green hat and claim to be a Padanian, and many northern Italians actually did so. In any case, such processes of realignment are likely to leave not only written evidence, but also material traces. If

${ }_{63}$ Jordanes, Getica XLIX, ed. Mommsen 125. Jordanes' report was written a century after the funeral, so it may well represent expectations rather than fact.

${ }^{64}$ István Bóna, Das Hunnenreich (Budapest/Stuttgart 1991); Michel Kazanski, L’archéologie de l’‘Empire’ hunnique. A propos d'un livre récent, in: Francia 20, 1 (1993) 127-145. More convinced of the specifically Hunnic character of some of the finds from the period: Bodo Anke, Studien zur reiternomadischen Kultur des 4. bis 5. Jahrhunderts. 2 Bde. (Weißbach 1998). But see also the contribution by Csanád Bálint, in this volume.

65 Claus von Carnap-Bornheim/Jørgen Ilkjaer, Illerup Ådal 5, Die Prachtausrüstungen, Textband (Jütland Archaeological Society Publications 25, 5, Aarhus 1996).

${ }^{66}$ Cf. Guy Halsall, Settlement and Social Organisation. The Merovingian Region of Metz (Cambridge 1995); Bonnie Effros, Merovingian Mortuary Archaelogy and the Making of the Early Middle Ages (Berkeley/Los Angeles/London 2003).

${ }^{67}$ Das germanische Fürstengrab von Mušov in Mähren, ed. Jaroslav Peška/Jaroslav Tejral (Monographien des RGZM 55, 1-3, Mainz 2002); Guy Halsall, Childeric’s grave, Clovis' succession, and the origins of the Merovingian kingdom, in: Society and Culture in Late Antique Gaul: Revisiting the Sources, ed. Ralph W. Mathisen/Danuta Shanzer (Aldershot 2001) 116-133; Martin Carver, Sutton Hoo: Burial Ground of Kings (London 1998).

${ }^{68}$ Frans Theuws, Ethnicity, grave goods and the rhetoric of burial rites in Late Antique northern Gaul, in: Ethnic Constructs in Antiquity. The Role of Power and Tradition, ed. Tom Derks/Nico Roymans (Amsterdam, forthcoming).

${ }^{69}$ Wenskus, Stammesbildung und Verfassung; Herwig Wolfram, Typen der Ethnogenese. Ein Versuch, in: Die Franken und die Alemannen bis zur "Schlacht bei Zülpich” (496/97), ed. Dieter Geuenich (RGA Erg. Bd. 19, Berlin/New York 1998) 608-627; Walter Pohl, Tradition, Ethnogenese und literarische Gestaltung: eine Zwischenbilanz, in: Ethnogenese und Überlieferung. Angewandte Methoden der Frühmittelalterforschung, ed. Karl Brunner/Brigitte Merta (Veröffentlichungen des Instituts für Österreichische Geschichtsforschung 31, Wien 1994) 9-26.

${ }^{70}$ Pierre Bourdieu, Sozialer Sinn. Kritik der theoretischen Vernunft (Frankfurt a. Main 1993); Pohl, Telling the difference; MüllerScheeßel/Burmeister, Einführung; Curta, Some remarks; Von Rummel, Habitus barbarus. 
we regard, with Guy Halsall, "furnished burial as an active strategy involved in the creation, maintenance and negotiation of social reality, rather than as a passive reflection of 'ethnicity', religion or social hierarchy”, then this is an approach that leaves sufficient space to accommodate analyses of the formation and negotiation of ethnic identities. ${ }^{71}$

At the end of Antiquity, we can indeed observe identities under construction. This has a number of methodological consequences. First of all, the process of the transformation of the Roman world led, in many ways, to a crisis of identity, not least of those who had come from beyond the frontiers to settle on Roman territory. ${ }^{72}$ There were many reasons for them to maintain, or even, after a few generations, re-invent what distinguished them from other inhabitants of those Roman provinces. But if many barbarians on Roman territory chose not to bury their dead the barbarian way, we should not neglect that fact. The sparse 'Gothic' finds from Gothic Italy, Gaul and Spain indicate that many noble Goths must have adapted to Roman ways, in life as in death. ${ }^{73}$ Sociological studies of modern ethnicity have received many of their impulses from observing the behaviour of successive generations of immigrant groups in the USA, and some of their models may help to understand immigrant groups in the later Roman Empire. ${ }^{74}$ One of the oldest debates in archaeology is whether migrations or internal developments have prompted cultural change. ${ }^{75}$ In the light of the complex migration-age evidence, this is not necessarily an alternative.

In the post-Roman regna, status came to be linked with military and/or political participation in the rule of the kingdom. A Frank or a Lombard in the full sense was one who had access to court or at least participated in military expeditions, so demonstration of status may coincide with the assertion of ethnic identites in many cases. Ethnic groups acted, they engaged in politics and went to war. Participation in all of these concrete actions could vary, but they were seen as representative of an ethnic collective whose exact shape and extension remain vague for most of the time. We can only guess how many Lombards came together in the circus at Milan when Agilulf's two-year-old son Adaloald was proclaimed king in the August of 604; but he was raised super Langobardos, over all of them. ${ }^{76}$ Representing the Lombards thus became a special way of being Lombard; identifying oneself as Lombard can be seen as a 'strategy of distinction'. ${ }^{77}$

Both historical and archaeological evidence essentially show the same picture: it is often relatively easy to define groups who belong to a people in the full sense, and want to demonstrate that. For instance, it is quite plausible that the men buried with weapons and the women with traditional attire at Castel Trosino, Nocera Umbra or Trezzo d'Adda were in fact Lombards, or at least people of Roman origin who wanted to be buried like 'real' Lombards. ${ }^{78}$ If we find a rather uniform mode of high status display in a certain region that includes signs of military and political participation - weapons, precious objects, artifacts resembling those represented in the core areas of the kingdom - chances are that this is a trace of demonstrating to a predominantly local audience that the deceased belonged to the dominant group of the kingdom. But this picture becomes rather blurred at the edges, and, for instance, the interpretation of cemeteries without grave goods, in all their variety, is difficult: were these Romans, poor Lombards, or christianized barbarians? ${ }^{79}$ Moreover, early medieval weapon burials obviously do not simply display status and/or ethnicity, but can be rather specific

\footnotetext{
${ }^{71}$ Halsall, Burial writes 61.

72 Walter Pohl, Die Völkerwanderung. Eroberung und Integration (Stuttgart/Berlin/Köln $\left.{ }^{2} 2005\right)$.

${ }^{73}$ Volker Bierbrauer, Die ostgotischen Grab- und Schatzfunde in Italien (Biblioteca degli Studi Medievali 7, Spoleto 1974); Michel Kazanski, Les Goths. I Ir-VII après J.-C. (Paris 1991); Gisela Ripoll López, The arrival of the Visigoths in Hispania: population problems and the process of acculturation, in: Strategies of Distinction. The Construction of Ethnic Communities, 300-800, ed. Walter Pohl/Helmut Reimitz (The Transformation of the Roman World 2, Leiden/Boston/Köln 1998) 153-188; von Rummel, Habitus barbarus 323-336.

${ }^{74}$ Ethnicity - Theory and Experience, ed. Nathan Glazer/Daniel P. Moynihan (Cambridge-Mass./London 1975).

75 Trigger, A History of Archaeological Thought.

${ }^{76}$ Paulus Diaconus, Historia Langobardorum IV, 30 (ed. Ludwig Bethmann/Georg Waitz, MGH SS rer. Langob., Hannover 1878) 12-187, at 127.

77 Walter Pohl, Geschichte und Identität im Langobardenreich, in: Die Langobarden - Herrschaft und Identität, ed. Walter Pohl/ Peter Erhart (Forschungen zur Geschichte des Mittelalters 9, Wien 2005) 555-566.

${ }^{78}$ Volker Bierbrauer, Frühe langobardische Siedlung in Italien: Gräberarchäologie und Siedlungsarchäologie - methodische Probleme ihrer Interpretation, in: I Longobardi dei ducati di Spoleto e Benevento, Atti del XVI congresso internazionale di studi sull'alto medioevo (Spoleto 2003) 29-78. See also Lidia Paroli, La necropoli di Castel Trosino: un laboratorio archeologico per lo studio dell'età longobarda, in: L'Italia centro-settentrionale in età longobarda, ed. Lidia Paroli (Florenz 1997) 91-112.

79 See, for instance, Cornelia Rupp, Langobardische und romanische Grabfunde in Umbrien, in: I Longobardi dei ducati di Spoleto e Benevento, Atti del XVI congresso internazionale di studi sull'alto medioevo (Spoleto 2003) 669-700. For the regional variety of types of burials in Lombard Italy, see Irene Barbiera, Sixth-century cemeteries in Hungary and Italy: a comparative approach,
} 
in their references. Fifth-century weapon burials often display a particularly wide horizon, so that the closest parallels to a sword found in Beja (Portugal) can be detected north-east of the Black Sea and along the Middle Danube. That does not necessarily mean that the man buried at Beja came from the east, but rather hints at the wide circulation of weapons used by the Roman military and barbarian warriors alike. ${ }^{80}$ In Gothic settlement areas, we often find high-status males buried without weapons. ${ }^{81}$ Anglo-Saxon sword burials do not always seem to contain swords used by the deceased, but old ones that must have circulated for a long time; the numbers of deposition do not seem to coincide with periods of frequent wars. ${ }^{82}$ By contrast, the sword burials at Obermöllern seem to indicate a rather straightforward display of warrior status (see the contribution by Jörg Kleemann, in this volume). Swords deposed in Merovingian Northern Gaul often came from distant areas, another clear indicator of circulation and exchange in a complex network, perhaps also in a ritual context. ${ }^{83}$ In some cases, even women may have been buried with weapons. ${ }^{84}$ These are a few examples of the manifold meanings that the same kinds of objects may acquire in early medieval burials. Still, we can locate all of these practices within kingdoms whose basic outline is known from written sources. Perhaps there is no need to argue in every case whether individuals or groups of burials in, for instance, the Frankish kingdoms were of Frankish or foreign origin, or whether Visigoths or Romans were buried in the cemetries on the Meseta from the Visigothic period. ${ }^{85}$ Rather, we may want to know how they placed themselves in the web of cultural codes and exchanges within that kingdom.

Negotiations of status and identity in the regna were reinforced by extensive exchange. We can imagine the late Roman and the post-Roman societies as being built on reciprocity. This did not imply a symmetry of status, but of recognition of the respective social roles. In this process, symbolic gestures and objects were exchanged.$^{86}$ In Late Antiquity, the arena of these exchanges hardly coincided with ethnic boundaries. There were several rivalling systems of recognition in late Rome: the imperial networks in their changing configurations, the conservative value system of pagan senators, the new spritual and institutional hierarchy of Christianity, and, of course, the Roman-barbarian military elites. Much effort by barbarian newcomers went into earning recognition within the military sphere, and as successful soldiers beyond it. Ethnic distinctions obviously mattered less than the wider system of reciprocity that the crumbling res publica still had to offer. It took some time until barbarians and provincial elites were realigned in the smaller exchange networks in the regna. This is a change that we would like to know more about, and archaeology may have considerable evidence to offer. Ethnic classification is less helpful in understanding this process than a careful specification of which groups can be shown to have interacted when and how within these new systems of identification.

Both archaeologists and historians have long been dissatisfied with the lack of clear distinctions between ethnic groups. There have been several attempts to arrive at a clearer picture by using statistical methods and computer seriation. ${ }^{87}$ In comparison to ethnic attributions on the basis of one or a few object types, these models have many merits. But it is doubtful whether the ethnic demarcations they aim to achieve correspond to actual ethnic groupings; statistical mappings may also obscure important inner differences. In fact, we should neither expect uniformity nor clear demarcations. Ties to a given ethnic group were stronger or weaker according to many factors, some rather stable (geographical distance, social status, strong local or differing ethnic

in: Die Langobarden - Herrschaft und Identität, ed. Walter Pohl/Peter Erhart (Forschungen zur Geschichte des Mittelalters 9, Wien 2005) 301-320. For the changing interpretation of 'poor' burials, see the contribution by Irene Barbiera in this volume.

${ }^{80}$ Michel Kazanski, Les tombes 'princières' de l'horizon Untersiebenbrunn, le problème de l’identification ethnique, in: L’identité des populations archéologiques (Antibes 1996) 109-126; von Rummel, Habitus barbarus 342-375.

${ }^{81}$ Volker Bierbrauer, Archäologie und Geschichte der Goten vom 1.-7. Jahrhundert. Versuch einer Bilanz, in: Frühmittelalterliche Studien 28 (1994) 51-171.

${ }^{82}$ Heinrich Härke, Warrior graves? The background of the Anglo-Saxon weapon burial rite, in: Past and Present 126 (1990) 22-43; id., The circulation of weapons in Anglo-Saxon society, in: Rituals of Power from Late Antiquity to the Early Middle Ages, ed. Frans Theuws/Janet Nelson (The Transformation of the Roman World 6, Leiden/Boston/Köln 1999) 377-400.

${ }^{83}$ Frans Theuws/Monika Alkemade, A kind of mirror for men: sword depositions in Late antique northern Gaul, in: Rituals of Power. From Late Antiquity to the Early Middle Ages, ed. Frans Theuws/Janet L. Nelson (The Transformation of the Roman World 8, Leiden/Boston/Köln 2000) 401-476; see also Bazelmans, Beyond power.

${ }^{84}$ Effros, Merovingian Mortuary Archaeology $162 \mathrm{f}$.

${ }^{85}$ Ripoll, The arrival of the Visigoths.

${ }^{86}$ Cf. Kate Cooper, The Fall of the Roman Household: Religion, Gender, and the Household in the Sixth Century (Cambridge 2007).

${ }^{87}$ Frank Siegmund, Alemannen und Franken, ed. Heinrich Beck/Dieter Geuenich/Heiko Steuer (RGA Erg. Bd. 23, Berlin/New York 2000); Peter Stadler, Quantitative Studien zur Archäologie der Awaren I (Mitteilungen der Prähistorischen Kommission der Österreichischen Akademie der Wissenschaften 60, Wien 2005); see also his contribution in this volume. 
traditions) and some rather variable (political context, personal ambitions, situational elements). Personal identities could thus be related in different manners to ethnicity. Statistical methods employed to define 'cultural models' should allow for such variables. Deciding on an appropriate ethnic label is not the ultimate goal of the interpretation of burial evidence. It may be more interesting to see how intensely, ambitiously, routinely, ambiguously or idiosyncratically an individual burial or a cemetery were related to the prevailing language of identity, or to other cultural repertoires as well.

\section{CONCLUSIONS}

Perhaps it is useful at this point to sum up some of the methodological observations for an archaeological (or interdisciplinary) reconstruction of early medieval identities:

1. As a rule, we cannot expect to find evidence for homogeneous, accomplished ethnic groups to whom a well-circumscribed population simply belonged. Even in archaic and generally stable societies, we cannot assume that its inhabitants were neatly classed in culturally distinct groupings. This is all the more so in times of rapid social and cultural change, such as the period between the $4^{\text {th }}$ and the $6^{\text {th }}$ centuries.

2. Ethnic integration could operate at several levels, from local and regional groups to supra-regional political units and generic and ethnographic terms. The respective cohesion and impact of such groupings could vary greatly. There is a wide range of possibilities as to which kind of ethnic group may be connected with an ethnonym in the written sources, with obvious implications for the interpretation of archaeological evidence.

3. Political agency played a key role especially where ethnicity was used to reinforce the coherence of military rule over large territories (as in the case of the Visigoths or Franks). Action taken by kings, by the potentes or by the whole army was then understood to represent the ethnic unit as a whole. To understand the barbarian elites that grabbed power in Western Roman provinces and their "cultural brokers" 88 , a functionalist model of ethnicity thus seems to be quite appropriate, for ideas of ethnic community were to a degree actively promoted.

4. To rely on ethnic solidarities, there had to be demonstrable differences; thus the new barbarian elites had to employ sophisticated 'strategies of distinction'. However, for a number of reasons these strategies do not correspond to clear sets of symbolic boundary markers. The cultural background of the new elites was too heterogeneous in many cases; they were operating within a set of barbarian stereotypes that had been used in a derogatory sense by generations of Romans; they used a semantic of self-representation that had been quite common among the late-Roman military for some time; the overwhelming 'symbolical capital' of the Roman Empire and of Christianity was not easily matched by other, 'genuinely barbarian' forms of symbolic expression; and, finally, most of the barbarian gentes were more interested in vertical social distinctions (vs. the provincial population they had come to rule) than in horizontal boundary markers (vs. other gentes elsewhere). ${ }^{89}$ Therefore, clear and stable ethnic boundaries recognizable by easily-distinguishable symbolic markers are likely to be the exception and not the rule.

5. Even where ethnicity was politically promoted, it could not simply be invented. "Ethnicity cannot be sustained without reference to an inventory of cultural traits"..$^{90}$ Thus, ethnic identities were not simply analogous with culture. But they could and had to make use of the cultural landscape, the exchange networks, the spheres of communication, the forms of 'habitus' and the symbolic languages current at the time.

6. As a methodological principle, 'population' (as defined by distinctive features selected by modern observers, for instance cultural groups or populations defined by their DNA) and 'people' (as a historical agent) should never be equated. But if we employ the right sets of criteria, 'populations' that we define can provide the cultural inventory at the basis of contemporary efforts to delineate ethnic identities.

7. The functionalist approach may be much less appropriate for other forms of ethnic identity. We have to recognize that early medieval political uses of ethnic identity in the West were more an exception than the rule, even in the post-Roman world. Here, strong rulership, the use of a language of ethnic agency in written sources, and the presence of symbolic objects in the material remains seem to be related. The early

\footnotetext{
${ }^{88}$ Helmut Reimitz, Die Historiographie der Zukunft. Geschichte und Identität in den Frankenreichen der Merowinger- und Karolingerzeit (Habilitationsschrift, Wien, forthcoming).

89 See Pohl, Telling the difference.

${ }^{90}$ Curta, Some remarks 166, with reference to Thomas Hylland Eriksen, The cultural contexts of ethnic differences, in: Man 26 (1991) 127-144.
} 
Slavs constitute a puzzling example of a society where neither strong rulers, nor specific ethnonyms for groups acting in unison, nor a wealth of symbolical objects can be demonstrated. ${ }^{91}$

8. The ethnic landscape of late antique and early medieval Europe was far from the balanced world of midsized tribes that still influences current ideas about ethnicity. Thus, instead of looking for one form of ethnicity (however defined), archaeological research has to be flexible enough to look for rather different types of identification and 'identificability'. It is up to debate whether, and in what cases, the agency and the ethnic practice of a people described in the sources may have left traces in the archaeological record. If archaeological methods can lead to historical conclusions, it is not the straighforward identification of any given material with an ethnic group. Many types of evidence are not ethnically significant. ${ }^{92}$ But I would hope that an archaeology of identity, where it is possible, can offer more than simple classification - rather, detect the traces of the many shades and changes of ethnic identity in the context of other forms of identification.

\footnotetext{
${ }^{91}$ The exceptions to this rule are indicative, for instance the Slavs along the Lower Danube in the $6^{\text {th }} / 7^{\text {th }}$ century or in Carinthia in the $8^{\text {th }}$; in both cases, political organisation and burials with precious objects seem to show a roughly parallel development. See Curta, The Making 190-310.

${ }^{92}$ Pohl, Telling the difference.
} 
